\title{
NATURE'S FIVE ELEMENTS: CONNECTION WITH THE HUMAN BODY, THEIR ROLE IN HUMAN LIFE AND WELLNESS
}

\section{D MARATHE ${ }^{1} \&$ JAGDISH ACHARYA ${ }^{2}$}

${ }^{I}$ Satish Pradhan Dnyanasadhana College, Thane 400604, Maharashtra, India

${ }^{2}$ Sadguru Academy, At and Post Panchwad, Taluka Wai, Dist. Satara, Maharashtra, India

\begin{abstract}
Ayurveda (with its origin in the Vedas) and Yoga are ancient life sciences of Indian origin. Ayurveda observes that nature's five elements, known as Panch-Tatva or Panch-Mahabhutas compose the human body. The Indian doctrine of five elements believes that the universe is composed of five elements, which are Water (Aap or Jal), Air (Vayu), Fire (Agni or Tej), Space or ether (Akash) and Earth (Prithvi). These elements are present in a balanced state in the universe. The seers believed that all Nature is part of the individual, since we are all created from, exist in and return to Nature. The five elements can be thought over as multidimensional and have macro and micro levels of existence in the human body. In the present study, the authors correlate Nature's five elements with the human body in terms of their role in human life and wellness.

KEYWORDS: Panchtatva, Panchamahabhute, Tri-Dosha, Vat, Pitta, Kapha, NFE (Nature's Five Elements)
\end{abstract}

Received: Jun 10, 2020; Accepted: Jun 30, 2020; Published: Jul 27, 2020; Paper Id.: IJMPERDJUN2020472

\section{INTRODUCTION}

According to Vedic science, when spirit (in Sanskrit called Purusha)takes the form of life (in Sanskrit called as Prakruti),it is made up of five elements, viz. Earth (Pritvi), Water (Jala), Fire (Teja or Agni), Air (Vayu) and Space (Akasha). An element is a substance (in Sanskrit dravya) which has associated properties (qualities) termed as guna. The relation between a substance and its properties (dravya-guna) is very important inhuman perception through the five senses. Vedic schools of philosophy including Ayurveda and Yoga Sutras view the whole world and the universe as an integrated entity made up of these five elements. All matter is composed of the five basic elements mentioned above. They are known as Panchamahabhuta, which in here their properties. The fundamental structural basis of all living beings, including plants, animals and humans are Nature's Five Elements (hereafter referred to in the abbreviated form NFE). These are the constituent parts that come together to create our body, mind and the experience of living.

Five senses are associated with these NFE as in the following manner:

- $\quad$ Space is associated with Ear (hearing/sound)

- $\quad$ Air with Skin (touch)

- $\quad$ Fire (sight / colour)

- Water with tongue (taste).

- $\quad$ Earth with nose (smell). 
The five fingers of the hand (Sanskrit names given in brackets) are also associated with NFE as

- Index finger (Targani): Air

- Middle finger (Madhyama): Space

- $\quad$ Ring finger (Anamika): Earth

- $\quad$ Little finger (Kanishthika): Water

- Thumb (Angushtha): Fire

\section{FIVE ELEMENTS AS STATES OF MATTER}

Each of the five elements can be looked upon as a state of matter. Earth (Prithvi) is not to be considered simply as soil, but everything in nature that is in solid state. Water (Jala) is to be considered as everything that is liquid or fluid matter. Air (Vayu) refers to everything in gaseous form. Fire (Agni) is that part of Nature which transforms one state of matter into another. Fire transforms the solid state of water (ice) into liquid state i.e. water itself and then into gaseous state (steam). In general, a solid can be transformed into liquid and liquid into gaseous form by fire means by providing heat. Space (Akash) is needed for everything in our body. We need space to eat food, to transfer the food to bloodstream and so on.

All the five elements have specific relationships like assisting or resisting each other based on their nature, form and the laws of nature. For example, fire and water - as fire can evaporate water or water can destroy fire. When this is seen in terms of the human body, too much of the fire element can cause inflammation, while too much of water will hamper digestion. In this context fire and water oppose each other. Earth and water love or assist each other, so are air and fire. Air enhances fire.

\section{ELEMENTS IN THE BODY AND THEIR QUALITIES AND FUNCTIONS}

According to Ayurveda and Yoga Shastra, NFEs are responsible for the overall health of human beings. Any disorder in the human body indicates imbalance of one or more of these elements. Ayurveda classifies three intrinsic tendencies known as 'tri-dosha' (tri means three and dosha here means tendencies), viz. Vata, Pitta and Kapha, which exist in every human body in some form and relate to the five elements as follows:

- Akash and Vayu together constitute what is known as Vata.

- $\quad$ Agni and Jala make Pitta

- Water and earth create Kapha

Each of the five elements forms different structures in the body. Earth forms solid structures, such as bones, muscles, skin, tissues, and hair etc. Water forms saliva, urine, semen, blood, and sweat. Fire generates hunger, thirst, and sleep. Air is responsible for all movement, including expansion, contraction, and suppression. Space forms physical attraction and repulsion, as well as fear and anxiety.

When a sperm and ovum unite to form a fertilized egg, all five elements are actively involved in formation of embryo and its development into foetus. Earth gives weight and gives position to it. Water gives moisture and nourishes it. 
Fire gives energy for development and Air helps for cell division. Akash (space) gives space for development of the foetus. These elements are further visualised and manifested in the human body (as well as in animals) in the following manner:

- $\quad$ Earth element (Bones and Muscles)

- Water element (Blood)

- $\quad$ Air element (Breath)

- $\quad$ Fire element (Heat)

- $\quad$ Space element (Emptiness within).

\section{IMBALANCE OF FIVE ELEMENTS IN THE BODY}

The sequential ordering of the five elements and their properties is the fundamental aspect of the development of the human body. Imbalance of an element means either an excess quantity or less than required.

\section{Water Element}

It is important to take in the qualities of water when one feels too warm, ungrounded, dehydrated, rough, lacking in selfesteem, obstructed and immobile, irritable with a sharp tongue, transparent and vulnerable. Since taste depends upon the water element for its manifestation, disorders of the ability to taste are due to an imbalance of the water element. It is interesting to note that the taste-buds in the tongue work only when water or saliva is present. Water is excreted from the body through the urethra as urine and also in the form of sweat. The imbalance in water element can be judged by observing changes in the taste and through alteration in urine and seminal fluid. Imbalance of Water element can lead to cold, sinusitis, asthma, swellings, blood thinning or blood clotting, problem of urination, diseases of reproductive organs.

\section{Fire Element}

The fire element represents the capacity of heat and light. Fire is the generator of energy in the body. Fire and the visual sense have a special relationship. Fire provides the light for perception. Since the sensory organ associated with it is eyes, disorders in visual perception can primarily be related to the fire element. Fire represents light, heat, lustre, energy, understanding, metabolism, and the power of transformation. It is the fire element because of which our body has the capacity to digest. Excess fire in the body results in a build-up of heat, while deficient fire results in a feeling of being cold. When there is excess heat, it needs to be reduced and hence body sweats and urinates more. A lack of fire element in the body slows down the metabolism. It also becomes difficult to digest new ideas. Imbalance of Fire element is indicated by coldness or fever, skin diseases, heat in body, loss of vital energy, acidity, diabetes, and mental disorders.

\section{Space Element}

It is the essence of emptiness. It is space that other elements fill. The ear is considered the associated sense organ of the element and voice (mouth) is its organ of action. Hearing loss as well as loss of voice can be related to imbalance of this element in the body. Space is omnipresent, without boundaries and formless. One can find the Space element in intestines, bladder and lungs. Nullification or overriding of space in the body contributes to symptomatic dysfunctions in these areas. Imbalance of Space element can lead to thyroid disorders, throat problems, speech disorders, epilepsy and diseases of the ear. 


\section{Earth Element}

It represents solid matter and the structure of the universe. The state of the earth element in the body and the capacity to smell are deeply connected. Excess earth element can obstruct the sense of smell, while deficient earth element can weaken the structures responsible for smell. Imbalance of Earth element can lead to weakness, obesity, weight loss and weight gain, bones or muscular diseases.

\section{Air Element}

Air enables blood circulation, breathing or movement, gliding of nerve impulses. It enables the thoughts to flow and the joints to propel our movement. In Yoga Sutras, Air (Vayu) is in five forms according to its direction of movement: inward (prana), outward (vyana), upward (udana), downward (apana) and that which balances and stabilizes these movements, a force that pulls toward the centre (samana). These five types of movements are called the five vayus and the five pranas. Imbalance of Air element leads to nervous disorders, blood pressure problems, lung disorders, physical pains and deformities, depression and locomotors ataxia.

\section{OBSERVATIONS, RESULTS AND DISCUSSION:}

Energy exists in the body in different forms such as bioenergy, electromagnetic energy, mechanical energy and chemical energy. These are collectively called the vital energy (in Yoga Sutras as pran shakti). Any imbalance in the five elements brings imbalance in the body. The authors offer following general observations gleaned from closely reading people in their sphere:

- Imbalance of the earth element in the body is associated with disorders of the bowel, large intestine, disorders of the solid parts of the body - bones, teeth etc, issues with legs, feet, knees, base of the spine, eating disorders and frequent illnesses.

- Imbalance of water element is associated with disorders of reproductive organs, spleen, loss of appetite, urinary system, menstrual difficulties, sexual dysfunctions and lack of flexibility.

- Imbalance of fire element in the body results into eating and digestive disorders, ulcers, diabetes, muscle spasms, muscular disorders, chronic fatigue and hypertension.

- Imbalance in the air gives rise to physical dysfunctions, disorders of the heart, lungs, thymus, breasts, arms, breathing problems, asthma, circulation problems, immune system deficiency, shoulder and neck tension, pain in chest and burn-out.

- Imbalance of space element can give rise to thyroid disorders, problems related to throat, speech and ear.

The authors identified from their study group individuals with imbalance of elements and advised them to work on the elements. This way of treating their health issues provided fantastic results. Therefore, the authors appeal to their readers that the study of five elements of nature is not an alternative to medicines, but it is to support the treatment of any disorder in the body. By consciously observing the body and the NFEs, one can prevent health issues as 'prevention is better than cure'.

The authors of this paper observe that an organization can attain sustainability when all parts of the system individuals within organisation, within society and within the biosphere - change and move together. This observation of 
the authors is based on a deep awareness of strategic actions which move towards sustainability. The determinants of human behaviour, individual change and engagement can be dealt with in terms of Nature's five elements. These interconnected and interdependent elements help us in the following ways:

- Fire - in designing an approach and performing it

- $\quad$ Air - understanding how change happens

- Water - understanding others behaviour and the influence of context

- $\quad$ Earth - understanding self and what one wants to achieve.

- $\quad$ Space - Thinking about possible 'Systems'

The relationship between the ancient Indian theory of five elements and the modern science is still not clearly known. Consequently, medical scientists, physicists and biologists have been making attempts to find clinical evidence and objective proof. However alternative medical practitioners and consultants in different areas have got results from their therapies and advices by dealing with the five elements in human body.

\section{CONCLUSIONS}

By understanding the positive and negative aspects of each element, one can tune one's mind to use each element in the most effective manner. So long as one maintains equilibrium of Nature's Five Elements in the body, one remains safe and healthy. The moment one comes across an imbalance in any of these Elements, one suffers either from health issues or issues at the workplace. The authors of this paper feel that if medical practitioners of all kinds study the five elements of nature and believe in their connection with the human body and correlate them with various health issues of their patients, it will support the treatment and quick recovery of the patients from illnesses. Purifying and taking charge of the elemental dimensions of one's making will bring tremendous sense of well-being and power.

\section{ACKNOWLEDGEMENT}

Authors acknowledge the help provided by Dr Manoj Patharkar.

\section{REFERENCES}

1. The Story of the Five Elements. By E. W. Edmunds J. B. Hoblyn. (The Library of Modern Knowledge.) Pp. viii + 264. London: Cassell and Co. Ltd., 1911

2. The Five Elements Guide by Kristoffer Lundholm, Renaud Richard Strategic Leadership towards Sustainability, BTH, Karlskrona, Sweden, 2005

3. Chawla L, 1999. Life paths into effective environmental action, The Journal of Environmental Education, 31(1), 15-26.

4. Purifying the Five Elements of Our Being by Dr.Swami Shankardev Saraswati Yoga Journal

5. The Hatha Yoga Pradipika by Yoga Swami Svatmarama, The Aquarian Press 1992

6. Akasha (Space) and Shabda (Sound): Vedic and Acoustical perspectives M.G. Prasad

7. Narayanopanishad in Atharvaveda. Collection of Veda mantras (Mantra Puspam), Ramakrishna Math, Bombay, 1991.

8. Mundakopanishad in Atharva Veda (section 2, canto1, Mantra3). Eight Upanishads (vol 2) Translation by Swami Gambhirananda, Advaita Ashrama, Calcutta, 1966. 
9. The Indian Theory of the five elements in studies in Hinduism by I.K. Watson, Navarag, Delhi, 1985

10. gfiles inside the government, Vol 9 Issue 8 November 2015, www.gfilesindia.com 